\title{
ODMOWA PRZYJĘCIA ODPADÓW KOMUNALNYCH DO REGIONALNEJ INSTALACJI PRZETWARZANIA ODPADÓW KOMUNALNYCH ZE WZGLĘDU NA "INNE PRZYCZYNY"
}

\section{Wprowadzenie}

Zgodnie z treścią art. 91 ust. 1 u.c.p.g. ${ }^{1}$ : prowadzący regionalną instalację do przetwarzania odpadów komunalnych, w granicach posiadanych mocy przerobowych, jest obowiązany zawrzeć umowę na zagospodarowanie zmieszanych odpadów komunalnych i odpadów zielonych ze wszystkimi podmiotami odbierającymi odpady komunalne od właścicieli nieruchomości, którzy wykonują swoją działalność w ramach regionu gospodarki odpadami komunalnymi lub z gminą organizującą odbieranie odpadów komunalnych, wchodzącą w skład regionu gospodarki odpadami komunalnymi.

Na mocy zaś art. 91 ust. 2 u.c.p.g.: w przypadku wystąpienia awarii regionalnej instalacji do przetwarzania odpadów komunalnych lub w innych przypadkach, o których mowa w art. 38 ust. 2 pkt 2 ustawy z dnia 14 grudnia 2012 r. o odpadach, uniemożliwiających przyjmowanie zmieszanych odpadów komunalnych lub odpadów zielonych od podmiotów odbierających odpady komunalne od właścicieli nieruchomości odpady te przekazuje się do instalacji przewidzianych do zastępczej obsługi tego regionu, wskazanych w uchwale w sprawie wykonania wojewódzkiego planu gospodarki odpadami.

\footnotetext{
* Dr, Uniwersytet w Białymstoku; e-mail: a.modrzejewski@uwb.edu.pl.

1 Ustawa z dnia 13 września 1996 r. o utrzymaniu czystości i porządku w gminach, tekst jednolity: Dz. U. z 2018 r. poz. 1454 (dalej: u.c.p.g.).
} 
Z treści art. 38 ust. 2 pkt 2 u.o. ${ }^{2}$ wynika, że to sejmik województwa określa regionalne instalacje do przetwarzania odpadów w poszczególnych regionach gospodarki odpadami komunalnymi oraz instalacje przewidziane do zastępczej obsługi tych regionów, w przypadku gdy znajdująca się w nich instalacja uległa awarii lub nie może przyjmować odpadów z innych przyczyn.

Ustawodawca, nie zdefiniował jednak wprost tego, co należy rozumieć pod pojęciem „,innych przyczyn”, z w powodu których możliwa jest odmowa przyjęcia odpadów do instalacji. Powstaje przy tym kluczowe pytanie czy, w przypadku braku realizacji płatności przez przedsiębiorcę odbierającego odpady, prowadzący Regionalną Instancję Przetwarzania Odpadów Komunalnych (RIPOK) może odmówić ich przyjęcia? Czy do kategorii „innych przyczyn” zaliczyć można również te o charakterze ekonomicznym? Można postawić przy tym hipotezę, że przyjęcie interpretacji, iż „inne przyczyny” mogą być również tożsame z przyczynami o charakterze ekonomicznym, nie wynika bezpośrednio z treści regulacji ustawy o odpadach i ustawy o utrzymaniu czystości i porządku w gminach, tym nie mniej możliwe byłoby to do wywiedzenia $\mathrm{z}$ doktryny na temat „urządzeń kluczowych” i wzajemności świadczeń. Brak jasności regulacji w tym zakresie utrudniać może efektywne prowadzenie działalności przez RIPOK.

\section{Interpretacja pojęcia „inne przyczyny"}

W orzecznictwie sądowoadministracyjnym wyrażane jest stanowisko, zgodnie z którym brak możliwości przyjmowania odpadów przez instalację regionalną - czyli niemożność wywiązania się z umowy, z przyczyn określonych w art. 38 ust. 2 pkt 2 u.o. - powinna być wykazana przez instalację, nie zaś przez przedsiębiorcę odbierającego odpady ${ }^{3}$. W wyroku z dnia 15 stycznia 2015 r. WSA w Gliwicach ${ }^{4}$ sąd wskazał, że przy inter-

2 Ustawa z dnia 14 grudnia 2012 r. o odpadach, tekst jednolity: Dz. U. z 2018 r. poz. 992 (dalej: u.o.).

3 Zob. wyrok NSA z dnia 3 marca 2017 r., II OSK 1473/15, Centralna Baza Orzeczeń Sądów Administracyjnych (dalej: CBOSA), www.orzeczenia.nsa.gov.pl [dostęp: 28.09.2017 r.].

4 Wyrok WSA w Gliwicach z dnia 15 stycznia 2015 r., II SA/Gl 1219/14, CBOSA. 
pretacji treści art. 38 ust. 2 pkt 2 u.o., należy mieć na uwadze charakter i zakres regulacji całego art. 38 u.o.

Jego adresatem jest sejmik województwa, a przepis dotyczy treści uchwały w sprawie wykonania wojewódzkiego planu gospodarki odpadami. Przepis art. 38 ust. 2 u.o. zawiera wskazania dotyczące obligatoryjnej treści tej uchwały, stanowiąc, że uchwała powinna określać po pierwsze regiony gospodarki odpadami, a po drugie regionalne instalacje do przetwarzania odpadów w poszczególnych regionach oraz instalacje przewidziane do ich zastępczej obsługi, gdy instalacja regionalna uległa awarii, z innych przyczyn nie może przyjmować odpadów.

„Zdaniem [WSA w Gliwicach], przepis ten nie odnosi się do obowiązków przedsiębiorców w sposób bezpośredni, przez wskazanie w jakich sytuacjach mogą korzystać $\mathrm{z}$ instalacji zastępczej. Delegacja z art. 38 ust. 2 [ustawy o odpadach] do wydania aktu prawa miejscowego nie uprawnia sejmiku województwa do określenia przypadków, uzasadniających przyjmowanie odpadów od przedsiębiorców przez instalacje zastępcze i określenia «innych przyczyn». W konsekwencji katalog przypadków uzasadniających przyjmowanie odpadów przez instalacje zastępcze ma charakter ustawowy. Inne przyczyny, dla których wskazana w uchwale regionalna instalacja do przetwarzania odpadów komunalnych nie może przyjmować odpadów, powinny być zatem określane z uwzględnieniem regulacji art. 38 ust. 2 pkt 2 [ustawy o odpadach]. Zwrot «inne przyczyny» ma charakter otwarty, jednak rodzaj tych przyczyn nie jest dowolny. W ocenie [WSA w Gliwicach], w katalogu tym mogą mieścić się tylko przypadki, które swoim charakterem i cechami odpowiadają pozostałym dwóm przypadkom przewidzianym $\mathrm{w}$ ustawie. Niewątpliwie awaria regionalnej instalacji oraz fakt, że nie została ona jeszcze uruchomiona, na mocy ustawy uprawniają instalacje zastępcze do przyjmowania odpadów. Są to przeszkody niezależne od woli samych przedsiębiorców, o charakterze zdarzeń losowych (awarie) lub obiektywnie istniejącego stanu faktycznego [...]. Mając na względzie regułę interpretacyjną eiusdem generis («tego samego rodzaju»), należy, w ocenie [WSA w Gliwicach], przyjąć, że również «inne przyczyny», z powodu których instalacja regionalna nie może przyjmować odpadów, powinny być ograniczone do przypadków o cechach zdarzeń losowych, niezależnych od działań i decyzji zainteresowanych podmiotów" ${ }^{\prime \prime}$.

5 Tamże. 
Powyższy pogląd znalazł potwierdzenie w orzeczeniu Naczelnego Sądu Administracyjnego ${ }^{6}$ (oddalającym skargę kasacyjną na ww. wyrok WSA w Gliwicach), zgodnie z którym „inne przyczyny”, z powodu których instalacja regionalna nie może przyjmować odpadów, powinny być więc ograniczone do przypadków o cechach zdarzeń losowych, niezależnych od działań i decyzji zainteresowanych podmiotów.

Orzeczenia te odnoszą się do pozycji przedsiębiorcy odbierającego odpady względem prowadzącego RIPOK i niemożności samodzielnego decydowania przez dostarczającego odpady o rezygnacji z usług instalacji (w tym odstąpienia od obowiązku podpisania umowy), tym niemniej pozwalają one na wykładnię tego, co można rozumieć pod pojęciem „innych przyczyn". Inne przyczyny, w rozumieniu przytaczanych powyżej orzeczeń, to przesłanki obiektywne i niezależne od prowadzącego instancję, do których nie zalicza się przyczyn mających charakter ekonomiczny.

Można w tym miejscu wskazać także na pogląd wyrażony w orzeczeniu WSA w Warszawie z dnia 2 października 2015 r., zgodnie z którym „inna przyczyna”, o jakiej mowa w art. 38 ust. 2 pkt 2 u.o. oraz w przepisach u.c.p.g., musi odnosić się do obiektywnych przeszkód w przekazaniu odpadów do RIPOK. Założeniem przywołanych ustaw jest, aby odpady trafiały do RIPOK. Przekazanie ich do innych instalacji, tj. instalacji zastępczych, powinno następować tylko w sytuacjach wyjątkowych, takich jak np. awaria. Z tego też względu pojęcie „inne przyczyny”, wskazane w ww. przepisie, muszą być interpretowane ściśle, mając na względzie nadrzędny cel ustawy - prawidłowe gospodarowanie odpadami ${ }^{7}$.

W przywoływanym powyżej orzeczeniu, sąd po raz kolejny analizuje przesłanki, z powodu których przedsiębiorca nie dostarcza odpadów do RIPOK. Z treści orzeczenia wyprowadzić można wniosek, iż obie strony umowy na dostarczanie odpadów są profesjonalistami i tak jak przedsiębiorca dostarczający odpady nie może zasłaniać się niekorzystnymi cenami proponowanymi przez instalację oraz wozić ich do instalacji zastępczej, tak podmiot prowadzący instalację, jako profesjonalista, winien realizować nadrzędny cel ustawowy w postaci zagospodarowania odpadów.

W tym samym orzeczeniu, Wojewódzki Sąd Administracyjny w Warszawie cytuje fragment uzasadnienia decyzji Samorządowego Kolegium

6 Zob. wyrok NSA z dnia 3 lutego 2017 r., II OSK 1256/15, CBOSA.

7 Wyrok WSA w Warszawie z dnia 2 października 2015 r., IV SA/Wa 1346/15, CBOSA. 
Odwoławczego, gdzie Kolegium podejmuje próbę określenia tego, co mieści się w ramach przesłanek uzasadniających odmowę przyjęcia odpadów. W ocenie Kolegium, stany faktyczne objęte dyspozycją „inna przyczyna", muszą być odnoszone do obiektywnych okoliczności takich jak np. zniszczenie lub zalanie dróg dojazdowych, blokada $\mathrm{z}$ powodu protestu itp. Muszą to być więc okoliczności związane z samym funkcjonowaniem, istnieniem instalacji - nie z przedsiębiorcą, który ją prowadzi czy też z otoczeniem prawnym (umowy o zagospodarowanie odpadów) lub z relacjami pomiędzy podmiotem przekazującym odpady i przedsiębiorcą prowadzącym RIPOK. Gdyby wolą ustawodawcy było uwzględnianie takich okoliczności, musiałoby to zostać wyraźnie wyrażone w ustawie, co nie ma miejsca w obecnie obowiązującym stanie prawnym.

Wojewódzki Sąd Administracyjny w Warszawie nie w pełni zgadza się z tak wyrażonym stanowiskiem, uznając, że jest to pogląd zbyt rygorystycznie traktujący przesłanki „innych przyczyn”. Zdaniem sądu, możliwe jest bowiem odniesienie owych przyczyn również do przesłanek mających charakter ekonomiczny. Sąd wyraża stanowisko, że: „[...] stwierdzony w oparciu o stosowną dokumentację obiektywny brak możliwości zawarcia przez podmiot zobowiązany do przekazywania zmieszanych odpadów komunalnych do instalacji RIPOK, umów o takie przekazywanie z podmiotami prowadzącymi przedmiotowe instalacje, może być skutecznie powoływany, jako usprawiedliwiony brak możliwości wywiązania się z ustawowego obowiązku, niemniej sytuacja tego rodzaju ma charakter zdecydowanie wyjątkowy i na pewno nie powinna być automatycznie utożsamiana z każdą taką sytuacją, w której podmiot zobowiązany do przekazywania odpadów napotyka pewne trudności z zawarciem tego rodzaju umów. Dla stwierdzenia obiektywnego braku możliwości zawarcia umów o przekazywanie odpadów koniecznym jest bowiem przekonujące wykazanie, że podmiot zobowiązany do przekazywania odpadów dołożył w stosownym czasie niezbędnej staranności celem doprowadzenia do zawarcia wspomnianych umów a pomimo tego, z żadnym z podmiotów prowadzących instalacje RIPOK umowy tej nie był w stanie zawrzeć (z przyczyn leżących po stronie tych podmiotów)" ${ }^{\prime}$.

Powyższy wywód można przenieść na grunt sytuacji, w której co prawda z przedsiębiorcą odbierającym odpady podpisana jest umowa, ale ten (przywożąc odpady do instancji) nie reguluje należności. Od-

8 Tamże. 
mowa przyjęcia odpadów musiałaby być poprzedzona wykazaniem, że prowadzący RIPOK dołożył daleko posuniętej, należytej staranności by umożliwić odbierającemu odpady uregulowanie płatności. Tylko bowiem wówczas, można założyć, że przyczyna, z powodu której odpady nie są przyjmowane, nie leży po stronie prowadzącego instalację, a ma charakter obiektywny. Zatem prowadzący instancję realizuje swój nadrzędny cel (w postaci zagospodarowania odpadów, powiązany z nadaniem mu statusu RIPOK), ale jednocześnie podejmuje działania zmierzające do uregulowania sytuacji ekonomicznej ${ }^{9}$. Na pewno nie wypełnia dyspozycji normy sytuacja, w której przedsiębiorca, co prawda ma zaległości finansowe względem prowadzącego RIPOK, ale sukcesywnie dokonuje wpłat i podejmuje działania w kierunku naprawy sytuacji. Trudno wówczas uznać, że zaistniała obiektywna przesłanka, niezależna od obu stron umowy. Jeśli w takiej sytuacji RIPOK odmówiłby przyjęcia odpadów, wówczas należałoby kwalifikować taki przypadek, jako działanie jednostronne (nie zaś czynnik o charakterze obiektywnym).

\section{Doktryna urządzeń kluczowych}

Spotkać można stanowisko, zgodnie z którym pozycję RIPOK wiąże się z tzw. "doktryną urządzeń kluczowych” (essential facilities). Doktryna ta została wypracowana w orzecznictwie sądów amerykańskich, jako przeciwstawienie się antykonkurencyjnym praktykom przedsiębiorstw posiadających istotne (kluczowe) urządzenia i instalacje oraz pozycję dominującą na rynku. Z czasem doktryna ta została zastosowana również w orzecznictwie sądów UE oraz wspólnotowych organów ochrony konkurencji. Znajduje ona zastosowanie przede wszystkim w sektorach dawniej zmonopolizowanych, takich jak: energetyczny (linie przesyłu gazu, sprzedaż i dystrybucja energii elektrycznej), transportowy (dostęp do infrastruktury portowej, kolejowej, lotnisk), telekomunikacyjny czy audiowizualny ${ }^{10}$.

9 O kolizji interesów prywatnego i publicznego w zakresie realizacji usługi zagospodarowania odpadów wypowiadał się NSA w Warszawie w wyroku z dnia 14 stycznia 2016 r., II OSK 1896/15, CBOSA.

10 Zob. K. Sampławski, Rola instalacji w systemie, "Gospodarka Odpadami” z dnia 21.10.2013, http:/ / www.pigo.org.pl/darek/KS\%20Legal\%20Newsletter\%20Odpady_10\% 202013_2.pdf [dostęp: 4.08.2017 r.]. 
Można również stwierdzić, że w obecnych uwarunkowaniach prawnych doktryna ta będzie się odnosiła do sektora gospodarowania odpadami komunalnymi.

W sytuacji, gdy na danym rynku duplikacja urządzeń kluczowych jest niemożliwa z powodów technicznych, prawnych lub ekonomicznych (koszty), istnieje ryzyko, że pomimo, iż zapewnienie dostępu jest technicznie możliwe, podmiot dominujący ( $w$ analizowanym przypadku RIPOK) odmawia dostępu na rozsądnych warunkach lub utrudnia dostęp do infrastruktury. Formy ograniczania dostępu mogą przybierać bardzo różny kształt.

Doktryna uwzględnia cztery zasadnicze przesłanki obowiązku przedsiębiorstw dysponujących urządzeniami kluczowymi udostępnienia ich swoim konkurentom: urządzenia kluczowe muszą być niezbędne do podjęcia przez konkurenta działalności gospodarczej na określonym rynku; odmowa udostępnienia urządzeń kluczowych musi prowadzić do wyeliminowania wszelkiej konkurencji na rynku sąsiednim, czyli na rynku powiązanym z rynkiem, na którym działa dominujące przedsiębiorstwo dysponujące urządzeniem kluczowym; aby uznać odmowę dostępu do urządzenia kluczowego za przejaw nadużycia pozycji dominującej, konieczny jest brak obiektywnych przyczyn uzasadniających odmowę; udostępnienie urządzenia kluczowego jest technicznie wykonalne oraz ekonomicznie możliwe ${ }^{11}$.

Przejawia się to $\mathrm{w}$ nałożeniu na przedsiębiorcę obowiązku udostępnienia urządzenia kluczowego. W literaturze słusznie wskazano, że znamiona zachowania określonego w art. 9 ust. 2 pkt 5 ustawy o ochronie konkurencji i konsumentów ${ }^{12}$ może spełniać odmowa kontraktowania (refusal to deal) przez dominanta, która może polegać m.in. na odmowie dostępu do urządzeń kluczowych ${ }^{13}$.

Prawdą jest, że kwalifikacja odmowy kontraktowania przez dominanta, jako zakazanego nadużycia, powinna być traktowana jako wyją-

11 Zob. M. Zalewska, Amerykańska koncepcja w unijnym prawie - essential facilities doctrine, „Przegląd Prawniczy Uniwersytetu im. Adama Mickiewicza” 2013, nr 2, s. 178.

12 Art. 9 ust. 2: „Nadużywanie pozycji dominującej polega w szczególności na: [...] 5) przeciwdziałaniu ukształtowaniu się warunków niezbędnych do powstania bądź rozwoju konkurencji”, ustawa z dnia 16 lutego 2007 r. o ochronie konkurencji i konsumentów, tekst jednolity: Dz. U. z 2019 r. poz. 369.

13 Zob. K. Kohutek, Ustawa o ochronie konkurencji i konsumentów. Komentarz, LEX el./ 2014. 
tek. Ogólną zasadą obrotu gospodarczego jest bowiem zasada swobody kontraktowej wynikająca z art. $353^{1}$ k.c. Jednakże przypadek ten zachodzi w razie odmowy przez dominanta dostępu do tzw. urządzeń kluczowych, a więc urządzeń, instalacji i infrastruktury, którymi dysponuje tylko dominant, a które są niezbędne do świadczenia usług przez konkurentów. Według doktryny traktującej na temat urządzeń kluczowych, przedsiębiorca posiadający pozycję dominującą $\mathrm{w}$ zakresie zarządzania dostępem do infrastruktury, bez której nie jest możliwe świadczenie określonego rodzaju usług, dopuszcza się nadużycia pozycji dominującej, jeżeli sam infrastrukturę tę użytkuje oraz bez obiektywnego uzasadnienia odmawia przedsiębiorcom dostępu do tych urządzeń bądź też udziela im takiego dostępu na warunkach mniej korzystnych, niż ustalone dla swych własnych usług. „Każde odmienne traktowanie przedsiębiorców w zakresie udostępniania im urządzeń kluczowych musi mieć swoje obiektywne uzasadnienie oraz być niedyskryminujące, albowiem w przeciwnym razie odmowa dostępu przez dominanta stanowi nadużycie jego pozycji dominującej i w przypadku braku istnienia realnego substytutu danego urządzenia przedsiębiorca może zostać zobligowany do umożliwienia innym przedsiębiorcom dostępu do tej infrastruktury"14.

W piśmiennictwie wskazuje się, że przesłankami, których łączne spełnienie pozwala uznać daną praktykę za odmowę dostępu do urządzeń kluczowych, stanowiącą nadużycie pozycji dominującej, są: „znaczne prawdopodobieństwo wyeliminowania konkurencji na skutek odmowy dostępu do danego urządzenia (przesłanka eliminacji konkurencji), a także brak obiektywnego uzasadnienia dla odmowy (przesłanka braku obiektywnego uzasadnienia) oraz niezbędność dostępu do danego urządzenia (przesłanka niezbędności)"15.

W literaturze przedmiotu problematykę urządzeń kluczowych (w przypadku RIPOK), również odnosi się głównie do kwestii technicznych niemożliwości przyjęcia odpadów do instancji. Odmowa będzie zatem dopuszczalna w przypadku braku obiektywnej możliwości przyjęcia odpadów, co najczęściej będzie powiązane właśnie z kwestiami technicznymi, np. w takich przypadkach jak: działanie siły wyższej (w tym awarii), gdy dany rodzaj odpadów nie jest obsługiwany przez instalację; odpady

14 Wyrok Sądu Apelacyjnego w Warszawie z dnia 10 lutego 2016 r., VI ACa 77/15, http:/ / orzeczenia.waw.sa.gov.pl/ [dostęp: 28.09.2017 r.].

15 K. Kohutek, Ustawa o ochronie konkurencji i konsumentów... 
nie spełniają wymaganych standardów na podstawie przeprowadzonych testów zgodności, brak wystarczających mocy przerobowych ${ }^{16}$.

Wydaje się jednak, że możliwym jest przyjęcie, iż w sytuacji jeśli dostarczający odpady nie reguluje przez dłuższy czas należności, wówczas udostępnianie RIPOK, jako urządzenia kluczowego, nie jest możliwe zarówno z przyczyn obiektywnych jak i ekonomicznych.

W literaturze zachodniej podkreśla się, iż odmowa zawarcia umowy dotyczącej dostępu do urządzenia kluczowego może zostać uznana za naruszenie prawa wyłącznie wtedy, gdy ma na celu monopolizację określonego rynku poprzez wykluczenie aktualnych lub potencjalnych konkurentów ${ }^{17}$. Zauważyć należy, że odmowa przyjęcia odpadów do zagospodarowania nie zmierza do wyeliminowania z rynku konkurencji (zarówno zagospodarowujący odpady jak i ich dostawca, świadczą odmienne zakresowo usługi), ale bardzo istotne jest, by analogiczne rozwiązania i analogiczne podejście stosowane było wobec wszystkich potencjalnych dostawców odpadów. Uzasadnienie odmowy przyjęcia odpadów musi być szczegółowo opisane i odnosić się do kwestii obiektywnych (w literaturze przedmiotu utożsamianych głównie ze względami technicznymi).

\section{Wzajemność świadczeń}

Prowadzącego RIPOK i dostarczającego odpady wiąże umowa cywilnoprawna określająca wzajemność świadczeń. Zgodnie z treścią art. 487 $\S 2 \mathrm{k.c.}^{18}$, umowa jest wzajemna, gdy obie strony zobowiązują się w taki sposób, że świadczenie jednej z nich ma być odpowiednikiem świadczenia drugiej. Zgodne z treścią art. 488-490 k.c., świadczenia będące przedmiotem zobowiązań z umów wzajemnych (świadczenia wzajemne) powinny być spełnione jednocześnie, chyba że z umowy, z ustawy albo z orzeczenia sądu lub decyzji innego właściwego organu wynika, iż jedna ze stron obowiązana jest do wcześniejszego świadczenia. Jeżeli świadcze-

16 Zob. K. Sampławski, Rola instalacji w systemie.

17 Zob. G. Knieps, The Three Criteria Test, the Essential Facilities Doctrine and the Theory of Monopolistic Bottlenecks, „Intereconomics” 2011, nr 1, s. 17.

18 Ustawa z dnia 23 kwietnia 1964 r. Kodeks cywilny, tekst jednolity: Dz. U. z 2018 r. poz. 1025 (dalej: k.c.). 
nia wzajemne powinny być spełnione jednocześnie, każda ze stron może powstrzymać się ze spełnieniem świadczenia, dopóki druga strona nie zaofiaruje świadczenia wzajemnego.

Jeżeli jedna ze stron obowiązana jest spełnić świadczenie wzajemne wcześniej, a spełnienie świadczenia przez drugą stronę jest wątpliwe ze względu na jej stan majątkowy, strona zobowiązana do wcześniejszego świadczenia może powstrzymać się z jego spełnieniem, dopóki druga strona nie zaofiaruje świadczenia wzajemnego lub nie da zabezpieczenia. Uprawnienia powyższe nie przysługują stronie, która w chwili zawarcia umowy wiedziała o złym stanie majątkowym drugiej strony.

Powstaje pytanie $\mathrm{w}$ jakim zakresie regulacje publicznoprawne mogą, po pierwsze, ograniczać swobodę zawierania umów ${ }^{19}$, po drugie, mogą wpływać na treść zobowiązań umownych pomiędzy stronami. Swoboda umów polega w tym zakresie ograniczaniu w ten sposób, że przepis prawa wprost nakazuje zarówno RIPOK jak i dostawcy odpadów zawarcie umowy (bez względu na ewentualne wątpliwości przedsiębiorcy, np. w zakresie ceny). Ograniczenie swobody umów wynika z art. 91 ust. 1 u.c.p.g. w zw. z art. 38 ust. 2 pkt. 2 u.o., ale wprost dotyczy tylko kwestii obowiązku zawarcia umowy - nie jej późniejszego wykonywania. Przepisy u.c.p.g. i u.o. wpływają na obowiązek kontraktowania, ale nie odnoszą się do modyfikacji reguł k.c. w obszarze świadczeń wzajemnych - w tym sensie, że realizacja usługi wymaga płatności.

Należy zwrócić uwagę również na treść przepisów sankcjonujących. Zgodnie $z$ art. 9 za pkt 2 u.c.p.g., prowadzący instalację wskazaną w uchwale w sprawie wykonania wojewódzkiego planu gospodarki odpadami, który nie zawiera umowy na zagospodarowywanie zmieszanych odpadów komunalnych lub odpadów zielonych z podmiotem odbierającym odpady komunalne od właścicieli nieruchomości, który wykonuje swoją działalność $\mathrm{w}$ ramach regionu gospodarki odpadami komunalnymi podlega karze pieniężnej w wysokości 10000 zł. Ustawodawca założył więc, że karane będzie jedynie niepodpisanie umowy, nie zaś odmowa przyjęcia odpadów do zagospodarowania. W przypadku zaś instalacji zastępczych karze podlega instancja, która zgodnie z pkt 3 nie odbiera zmieszanych odpadów komunalnych, odpadów zielonych lub pozostałości z sortowania odpadów ko-

19 Art. $353^{1}$ k.c.: „Strony zawierające umowę mogą ułożyć stosunek prawny według swego uznania, byleby jego treść lub cel nie sprzeciwiały się właściwości (naturze) stosunku, ustawie ani zasadom współżycia społecznego". 
munalnych przeznaczonych do składowania od podmiotu przekazującego odpady komunalne do instalacji przewidzianej do zastępczej obsługi danego regionu, wskazanej w uchwale w sprawie wykonania wojewódzkiego planu gospodarki odpadami - podlega karze pieniężnej w wysokości 10000 zł. W przypadku, jeśli instalacja „właściwa” nie jest w stanie zagospodarować odpadów, instalacja zastępcza jest do tego zobowiązana.

Oznacza to, że jeśli RIPOK z obiektywnych przyczyn nie może przyjąć określonych odpadów do zagospodarowania, wówczas prowadzący instalację zastępczą jest do tego zobowiązany, bez względu na powstałe okoliczności i przesłanki, które skłoniły prowadzącego instalację do odmowy przyjęcia odpadów. Można z tego wyprowadzić również wniosek, że o ile w przypadku RIPOK swoboda umów podlega ograniczeniu w ten sposób, że istnieje konieczność zawarcia stosownej umowy (bez względu na kwestie ekonomiczne), to obecne regulacje prawne nie ingerują już w kwestię wzajemności świadczeń pomiędzy RIPOK a dostawcą odpadów. Z kolei w przypadku instancji zastępczych, ustawodawca wprost nakazuje przyjęcie odpadów do instancji (bez względu np. na kwestie finansowe i brak regulacji odpowiednich świadczeń na zasadzie wzajemności) - sankcjonując brak wykonywania świadczenia w postaci przyjmowania odpadów. Podstawą przekazania odpadów do instalacji zastępczej będzie formalna odmowa ich przyjęcia do RIPOK skierowana do dostawcy odpadów. O takiej odmowie powinny być również poinformowane instancje zastępcze.

Założyć można również hipotetyczną sytuację, w której prowadzący instalację zastępczą, przyjmując odpady (na skutek odmowy ich przyjęcia przez RIPOK), a będąc do tego zobowiązanym ustawowo, wystąpi na drodze cywilnej z roszczeniem odszkodowawczym do RIPOK, próbując wykazać, że odmowa przyjęcia odpadów ze względów ekonomicznych - braku regulacji zobowiązań ze strony dostawcy - nie miała charakteru przyczyn obiektywnych i nie mogła być zaliczona do tzw. „innych przyczyn", o których mówi ustawa. Nie można wykluczyć zaistnienia przedstawionego scenariusza.

Z powyższych rozważań można wyprowadzić wniosek, że skoro strony muszą nawiązać stosunek prawny (nakazuje to bowiem ustawa), to treść samej umowy może być kształtowana dowolnie, w zakresie niesprzecznym z ustawą, która nie odnosi się do kwestii ekonomicznych, jako przesłanki uzasadniającej odmowę przyjmowania odpadów.

Podkreślenia wymaga jeszcze jedna okoliczność, otóż art. 38 ust. 2 pkt 2 u.o. adresowany jest do organu uchwałodawczego na poziomie 
województwa, wskazując na zakres uchwały w sprawie wykonania wojewódzkiego planu gospodarki odpadami. Można się zatem zastanowić, czy zasadnym jest poszukiwanie w tej normie podstawy prawnej do odmowy wstrzymania przyjmowania odpadów, w przypadku braku uregulowania płatności ze strony dostawcy odpadów. Czy nie zasadnym byłoby oparcie się tylko i wyłącznie na przepisach prawa cywilnego, jako znajdujących zastosowanie w przypadku braku regulowania zobowiązań.

W praktyce można spotkać umowy zawierane pomiędzy przedsiębiorcami prowadzącymi instalacje a dostawcami odpadów, w których znajdują się odpowiednie zapisy umożliwiające wstrzymanie odbiorów odpadów w przypadku braku uregulowania należności.

\section{Zakończenie}

Mając na uwadze przytaczane orzecznictwo sądowoadministracyjne, które kładzie nacisk głównie na względy techniczne, jako uzasadniające odmowę przyjęcia odpadów, i incydentalne orzeczenia wiążące odmowę ze względami ekonomicznymi, można powziąć uzasadnione wątpliwości, co do uznania, iż przesłankę „innych przyczyn” wiąże się również ze względami ekonomicznymi. Głównie uznaje się bowiem, że chodzi tu o czynniki techniczne, uniemożliwiające poprawne funkcjonowanie RIPOK. W literaturze zachodniej podkreśla się, iż odmowa zawarcia umowy dotyczącej dostępu do urządzenia kluczowego może zostać uznana za naruszenie prawa wyłącznie wtedy, gdy ma na celu monopolizację określonego rynku poprzez wykluczenie aktualnych lub potencjalnych konkurentów. Zauważyć należy, że odmowa przyjęcia odpadów do zagospodarowania nie zmierza, co do zasady, do wyeliminowania z rynku konkurencji (ze względu na prowadzenie odmiennych zakresowo czynności), ale bardzo istotne jest, by analogiczne rozwiązania i analogiczne podejście stosowane było wobec wszystkich potencjalnych dostawców odpadów. Zauważyć należy, że za brak przyjęcia odpadów do instalacji ustawa nie przewiduje sankcji. To wskazuje na fakt, że tylko obowiązek zawarcia umowy jest jednoznacznie określony przez prowadzącego RIPOK.

Słowa kluczowe: regionalna instancja przetwarzania odpadów komunalnych, odpady komunalne, odmowa przyjęcia, względy ekonomiczne 


\section{Bibliografia}

\section{Źródła}

Wyrok NSA w Warszawie z dnia 14 stycznia 2016 r., II OSK 1896/15, Centralna Baza Orzeczeń Sądów Administracyjnych (CBOSA), www.orzeczenia.nsa. gov.pl [dostęp: 28.09.2017 r.].

Wyrok NSA z dnia 3 lutego 2017 r., II OSK 1256/15, CBOSA.

Wyrok NSA z dnia 3 marca 2017 r., II OSK 1473/15, CBOSA.

Wyrok WSA w Gliwicach z dnia 15 stycznia 2015 r., II SA/G1 1219/14, CBOSA. Wyrok WSA w Warszawie z dnia 2 października 2015 r., IV SA/Wa 1346/15, CBOSA.

Wyrok Sądu Apelacyjnego w Warszawie VI Wydział Cywilny z dnia 10 lutego 2016 r., VI ACa 77/15, http://orzeczenia.waw.sa.gov.pl/ [dostęp: 28.09. 2017 r.].

\section{Literatura}

Knieps G., The Three Criteria Test, the Essential Facilities Doctrine and the Theory of Monopolistic Bottlenecks, „Intereconomics” 2011, nr 1, s. 17-21.

Kohutek K., Ustawa o ochronie konkurencji i konsumentów. Komentarz, LEX el./2014. Sampławski K., Rola instalacji w systemie, "Gospodarka Odpadami” z dnia 21.10.2013, http:/ / www.pigo.org.pl/darek/KS\%20Legal\%20Newsletter\%20 Odpady_10\%202013_2.pdf [dostęp: 4.08.2017 r.].

Zalewska M., Amerykańska koncepcja w unijnym prawie - essential facilities doctrine, "Przegląd Prawniczy Uniwersytetu im. Adama Mickiewicza” 2013, nr 2, s. 167-183.

\section{REFUSAL OF ACCEPTANCE THE MUNICIPAL WASTE TO THE REGIONAL MUNICIPAL WASTE TREATMENT BECAUSE OF THE OTHER REASONS}

\section{Sum mary}

The subject article is the case when the municipal waste are not acceptance to the Regional municipal waste treatment, because of economic reasons. This is the case when supplier of waste is not paying form the waste management.

Key words: regional municipal waste treatment, municipal waste, refusing of acceptance because economic reasons 


\section{ОТКАЗ ПРИНЯТИЯ КОММУНАЛЬНЫХ ОТХОДОВ К РЕГИОНАЛЬНОЙ ИНСТАЛЛЯЦИИ ОБРАБОТКИ КОММУНАЛЬНЫХ ОТХОДОВ, УЧИТЫВАЯ „ДРУГИЕ ПРИЧИНЫ" \\ Резюме}

Предметом статьи является анализ предпосылок по поводу, ведущий которых региональной инстанции обработки коммунальных отходов может отказать в принятии отходов, поставляемых сборщиком отходы, с подробным учитыванием причин об экономическом характере, лежащих по стороне доставки отходов.

Ключевые слова: региональная инстанция обработки коммунальных отходов, коммунальные отходы, отказ принятия, экономические причины 